\title{
The Comparison between Consumption and Production-based Zakat Distribution Programs for Poverty Alleviation and Income Inequality Reduction
}

\author{
Qurroh Ayuniyyah, Ataul Huq Pramanik, Norma Md. Saad, Md. Irwan Ariffin \\ International Islamic University Malaysia
}

\begin{abstract}
This study attempts to analyze the effect of consumption and production-based zakat distribution programs in eradicating poverty and reducing income inequality of the zakat beneficiaries by using the modification of the Center of Islamic Business and Economic Studies (abbreviated as CIBEST) model, Deciles method, Gini coefficient and Atkinson index. It takes the case study of 1,309 zakat beneficiaries managed by the National Zakat Board of Indonesia (abbreviated as BAZNAS) in three different cities and regencies including Bogor, Depok and Sukabumi. It suggests that the present zakat distribution programs conducted by BAZNAS can significantly alleviate poverty and reduce income inequality among zakat beneficiaries. It is observed that one year after receiving zakat programs, production-based programs have higher increase of the material and spiritual condition (represented by falah index) by 300 percentage points while households who obtained consumption-based programs rise by only 20 percentage points. It is also found that the Gini coefficient decreases by 0.017 points while Atkinson index falls by 0.042 points indicating that the income inequality among observed zakat beneficiaries are improved. This study has substantiated the role of zakat for poverty alleviation and income inequality reduction that can benefit development in general.
\end{abstract}

Keywords: Zakat Distribution Programs, Poverty, Income Inequality

\section{INTRODUCTION}

One of the important factors determining the success of zakat impact on development is a zakat distribution program. According to Zakat Act No. 23/2011, zakat distribution programs in Indonesia are divided into two categories namely, consumption and production-based programs. Hafidhuddin et al (2013) explain that the former should aim to fulfill basic needs of its recipients including health, food and education while the latter should intend to economically empower its recipients by providing financial assistance, business coaching and supervision to the zakat recipients. About two thirds of zakat collection is allocated for the former while the remaining one third for the latter (BAZNAS Report, 2015).

The difference between both programs specifically lies on their long-run goals. The consumptionbased programs aim at helping the beneficiaries without having long-term objective to realize the financial independence of the recipients. For instance, the distribution of zakat fund to help the victims of natural catastrophe in the country. The aid can 
be in the form of foods, clothes, victims evacuation, health facility and shelter.

The production-based programs aspire to achieve the financial independent status of the beneficiaries, which in the long-run they are expected to become zakat payers. For example, zakat community development (ZCD) integrates social and economic aspects of the people based on community and location. This empowers people by building their awareness and ability through training and coaching, with the main source of finance from zakat fund. Among ZCD programs that have been practiced are strawberry farmers empowerment in Bali, System of Rice Intensification development in Yogyakarta and water supply provision in East Kalimantan.

Moreover, a program called "Rumah Makmur BAZNAS" (BAZNAS Prosperity House) has a vision to attain economic well-being of the zakat beneficiaries by providing working capital access and promoting the spirit of Islamic economics. In this case, BAZNAS has the role to assist and monitor the mustahik throughout the program. The other examples of production-based programs include scholarship program, free-hospital facility and forming Islamic scholars cadres. These programs have the longrun objective to accomplish selfsufficiency of the mustahik.

From the previous explanation, it appears that the production-based zakat distribution programs have the ability to empower mustahik to achieve their well-being while consumptionbased programs mainly aim to fill out the basic necessities of the recipients. This research, hence, attempts to analyze and to compare the effect of consumption and production-based zakat distribution programs specifically in eradicating poverty and reducing income inequality of the zakat beneficiaries. It takes the case study of 1,309 zakat beneficiaries managed by the National Zakat Board of Indonesia (abbreviated as BAZNAS) in Bogor, Depok and Sukabumi by using questionnaire. The analytical tools used in the study are the modification of the Center of Islamic Business and Economic Studies (abbreviated as CIBEST) model that assesses poverty from material and spiritual perspectives. In addition, Deciles method, Gini coefficient and Atkinson index are also employed to measure the effect of zakat on income inequality reduction among zakat beneficiaries under consideration.

This paper comprises five sections including introduction as the first one. The second section is literature review followed by methodology in the third section. Section four deliberates results and analyses. Last section concludes the paper and presents some recommendations.

\section{LITERATURE REVIEW}

Beik (2013) argues that types of zakat program are one of important variables determining the success of income inequality reduction among zakat recipients. In general, BAZNAS (2015) classifies its distribution programs into two types of programs based on their objectives including consumption-based programs and production-based programs.

According to Beik and Ayuniyyah (2016), the Advisory Council of BAZNAS has issued a decision letter No. 001/DPBAZNAS/XII/2010 about guidance of collection and distribution of zakat. This decision also provides the principles related with the consumption and production-based 
distribution programs channeled to the beneficiaries. Accordingly, while consumption-based programs are generally aimed at fulfilling the daily basic needs of the recipients, production-based zakat distribution programs are disbursed by providing "qard al hasan" financing scheme for the beneficiaries. For the productionbased distribution programs, BAZNAS normally selects the recipients who are in the productive age group as they have a greater potential to change their life condition as compared to the recipients who are not in the production age group.

In relation with the role of zakat for poverty alleviation and income inequality reduction, there have been numerous empirical studies on this issue using quantitative approach in Indonesia. Beik (2013) uses the analytical tools to measure poverty and income inequality. These include the most commonly used Lorenz curve, Gini coefficient and Atkinson index to measure income inequality as well as headcount ratio, poverty and income gap measurement, Sen index and Foster, Greer and Thoorbeek (FGT) Index to measure poverty etc. By taking the case of Jakarta city, he finds that proper zakat distribution program is able to reduce the poverty incidence and income inequality by 16.79 percent and 0.57 percentage points respectively.

Anriani (2010), Purnamasari (2010), and Beik and Tsani (2015) also reveal similar findings. Anriani (2010) suggests that poverty incidence in Bogor regency can be reduced by 8.77 percent using the existing zakat distribution programs, while Purnamasari (2010) finds that the poverty rate can be reduced by 21.40 percent in Garut regency. Likewise, Beik and Tsani (2015) show that zakat can reduce poverty incidence in South Lampung regency by 18.60 percent.
However, poverty is actually a multidimensional concept in the sense that there is no definition that can provide a comprehensive view on poverty. Shirazi (1994), Pramanik (1993, 1998) and Narrayan (2000) are of the opinion that poverty is a state when individuals do not have enough resources to satisfy their basic needs in order to attain reasonably comfortable life. But based on multidimensional perspective they argue that it is difficult to comprehend poverty from income alone. Therefore, it is also important to see poverty from other perspectives especially from spiritual point of view. Imam Al-Ghazali (1980) divides poverty into two major categories namely, poverty with the relation to material and spiritual needs.

While conceptualizing the poverty concept from material and spiritual aspects, Beik and Arsyianti (2015) develop the Center for Islamic Economics and Business Studies (abbreviated as CIBEST) ${ }^{1}$ model to capture both elements. They define material poverty as the incapability to meet the material basic needs such as foods, clothes and shelter. The major cause of material poverty is the income inadequacy to meet those needs. On the other hand, spiritual poverty is defined as the inability of people to fulfill the minimum spiritual needs including such obligatory worships as prayer, fasting and paying zakat. This kind of poverty is caused by internal and external factors. The internal factors comprise the influence from self's lust and worldly desire, the lack of understanding on Islam and the domination of evil characters within

\footnotetext{
${ }^{1}$ The name "CIBEST model" is based on the research done by the Center of Islamic Economics and Business (CIBEST), Bogor Agricultural University in 2013 pertaining the Islamic Poverty Line concept.
} 
self such as laziness, bad temper and many more. The external factors include wrong family support, bad impact from external environment such as secularism, religious liberalism, atheism and many more, unsupported government policy and other external factors.

The attempts of the CIBEST model usage to analyze the role of zakat for poverty eradication have been made by Beik and Pratama (2015). By taking the case of Bogor regency, the study shows that after completing the program implemented with zakat, 63.7 percent of household are able to fulfill their material and spiritual needs. This is reflected through the decrease of the material, spiritual, and absolute poverty index and the increase of welfare (falah) index.

In line with that finding, Beik and Arsyianti (2015) also find that after joining zakat distribution programs within one year, the welfare (falah) index of the zakat beneficiaries in Jakarta can be raised by 96.8 percent measured by CIBEST index. Moreover, zakat can significantly lower the material poverty index by 30.15 percent and absolute poverty index by 91.30 percent. However, in this case, there are two households that have higher spiritual poverty index. It shows these two zakat receiver households experience diminishing spiritual values while they are materially better-off in the presence of zakat utilization program.

Despite a number of studies as delineated above, there still exists a gap in studying the empirical role of zakat in alleviating poverty and income inequality. First, the gap exists on the lack of past empirical studies particularly in Indonesia to compare the role of consumption and production-based zakat distribution programs in urban and rural areas.
Thus, any study to compare between both types of zakat distribution programs is expected to contribute the existing literature of zakat studies. Third, the gap also occurs on the issue of coverage of geographical area as vast as that of Indonesia. This kind of empirical research is still not conducted in many parts in Indonesia. Therefore, covering the cities and regencies of Bogor, Depok and Sukabumi will enrich the empirical studies of zakat.

\section{METHODOLOGY}

This study observes 1,309 respondents that are obtained through survey from January to April 2017. As mentioned earlier, it takes the case of BAZNAS in two different cities and regencies in West Java including Bogor, Depok and Sukabumi. The poverty analysis employs the Center of Islamic Business and Economic Studies (CIBEST) model with several alterations in order to obtain a more holistic result as it reveals material and spiritual aspects. The income inequality is measured by using Deciles method, Gini coefficient and Atkinson Index.

In terms of poverty analysis, this research examines two sets of data. First data set comprises pre-zakat household income and the second data set includes post-zakat household income. The pre-zakat household income data is obtained from BAZNAS in each regency before the respondents participate zakat distribution programs while the postzakat income data is acquired using questionnaires one year after they join zakat distribution programs. In terms of spirituality before and one year after zakat distribution programs, it is obtained through questionnaire. The CIBEST quadrant is used to derive 
index of each area in the quadrant including welfare index, material poverty index, spiritual poverty index and absolute poverty index. In our study, we change the term "welfare" with "falah". Mathematically, the falah index is formulized as follows.

$$
F=\frac{f}{N}
$$

Where:

$F=$ Falah Index that lies from 0 to 1

$f=$ The number of prosperous households of zakat payers

$N=$ The number of observations

Secondly, the material poverty index is formulized as follows.

$$
M p=\frac{N M_{p}}{N}
$$

Where:

$M p=$ Material Poverty Index that lies from 0 to 1

$N M_{p}=$ The number of materially poor but spiritually rich households. They fall under material poverty line, but their spiritual Likert scale at least equals to 3 .

$N=$ The number of observations

Thirdly, the spiritual poverty index is formulized as follows.

$$
S p=\frac{N S_{p}}{N}
$$

Where:

$S p=$ Spiritual Poverty Index that lies from 0 to 1

$N S_{p}=$ The number of materially rich but spiritually poor households. They fall above material poverty line, but their spiritual Likert scale is less than 3.

$N=$ The number of observations

Lastly, the absolute poverty index is formulized as follows.

Where:

$$
A p=\frac{N A_{p}}{N}
$$

$A p=$ Absolute Poverty Index that lies from 0 to 1

$N A_{p}=$ The number of materially and spiritually poor households. They fall under material poverty line and their spiritual Likert scale is less than 3.

$N=$ The number of observations

The number of , $N M_{p}, N S_{p}$, and $N A_{p}$ are simply determined by counting the number of households living in each quadrant. Those numbers can be valued when the standard of materially and spiritually poor are established. Accordingly, the standard of material line is derived from the minimum standard of material needs that has to be fulfilled by the household. The formula of this standard is as follows.

$$
M S=\sum_{i=1}^{N} P i M i
$$

Where:

$M S=$ Poverty line income (in terms of local currency)

$P_{i}=$ Price of goods and services $i$ (in terms of local currency)

$M_{i}=$ Minimum amounts of goods and services needed

In terms of income poverty line in five aforementioned areas under consideration, this study employs nishab standard of zakat of income as material standard. The nishab standard of zakat of income is the monetary value of $524 \mathrm{~kg}$ rice based on Regulation of Indonesian Minister of Religious Affair Number 52/2014. According to Presidential Instruction Number 5/2015, the governmentpurchasing price of each $\mathrm{kg}$ equals to IDR7300. Therefore, the material standard according to nishab is obtained by multiplying $524 \mathrm{~kg}$ of rice with the aforesaid governmentpurchasing price of each $\mathrm{kg}$ that equals to IDR3825200 or USD283.29. A household is classified as materially poor if its income is less than the value 
of $M S$. Otherwise, they are categorized as rich.

In terms of the indicators of spiritual needs, the spirituality model of CIBEST is opted over other models because of several considerations. First, the simplicity of the CIBEST model makes this model is applicable for large sample size. Second, although it needs several extensions, the indicators of spirituality in the CIBEST model have strong foundation according to the Quran and hadith. Third, the model has been also adopted as national policy by BAZNAS and hence the validity of the model has been solved.

The spiritual indicators of the CIBEST model are measured using Likert scale by evaluating the performance of household's worship and external factors including prayer, fasting, zakat and charity spending, household environment and government policy environment. The scale lies between 1 to 5 representing ascending performances in order. In other words, the higher scale represents the better spirituality.

For instance, if a household always performs obligatory and recommended prayer, fasting and pay zakat and charity, they are scored 5. On the other hand, if they never perform them and block other to perform those worships, they get 1 . Similarly, if the household and policy environments are conducive for the family members to perform worship, they are scored. The standard of spiritual poverty line equals to 3 showing the family only performs the obligatory worships or minimum performance of worships.

Nevertheless, despite its simplicity, the spirituality index in the
CIBEST model is confined on the mere three out of five pillars of Islam and the supporting environment of family and government. In the current study, the spiritual indicators are modified by adding some such other variables as the way of household members perform prayer (congregational or individual basis), the habit of reading Quran and the endeavor for acquiring Islamic knowledge as well as attending religious gathering or ceremonies. Besides that, the indicators also include one's foundation of Islamic creed, i.e. aqidah. The adjustments are expected to be able to capture spiritual condition of the household in more comprehensive way. The indicators of spirituality are presented in the following Table 1.

To support the additional spiritual indicators, this study employs verses in the Quran and hadith. For instance, the inclusion of Islamic creed (aqidah) is based on six pillars of faith and Islamic teaching practice in daily life supporting the hadith stating that poverty may lead to disbelief. The Quran 112: 1-4, 31: 22 and 33 are among verses that indicate the crucial aspect of believing Allah SWT. In terms of the way of household members in performing prayer whether in congregational (jama'ah) or individual basis, it is in accordance to the Quran 2: 43. Rasulullah (s.a.w) also said, "It is better to join another person and pray than to pray alone and it is more superior in the company of two men and the bigger congregation the more liked it is by Allah." (narrated by Abu Dawud, book of Kitabus Solah, hadith no. 554). 
Table 1. Spiritual Indicators

\begin{tabular}{|c|c|c|c|c|c|c|}
\hline \multirow{2}{*}{ Variables } & \multicolumn{5}{|c|}{ Likert Scale } & \multirow{2}{*}{$\begin{array}{l}\text { Spiritual } \\
\text { Standard }\end{array}$} \\
\hline & 1 & 2 & 3 & 4 & 5 & \\
\hline Belief & $\begin{array}{l}\text { Disbelieve } \\
\text { in Allah and } \\
\text { blocking } \\
\text { others to } \\
\text { believe }\end{array}$ & $\begin{array}{l}\text { Disbelieve in } \\
\text { Allah }\end{array}$ & $\begin{array}{l}\text { Believe in } \\
\text { Allah }\end{array}$ & $\begin{array}{l}\text { Believe in } \\
\text { Allah and have } \\
\text { positive } \\
\text { thought over } \\
\text { Him }\end{array}$ & $\begin{array}{l}\text { Believe in Allah, } \\
\text { have positive } \\
\text { thought over Him } \\
\text { and encouraging } \\
\text { others to believe }\end{array}$ & \\
\hline $\begin{array}{l}\text { Obligatory } \\
\text { Prayer }\end{array}$ & $\begin{array}{l}\text { Blocking } \\
\text { others to } \\
\text { pray }\end{array}$ & $\begin{array}{l}\text { Against the } \\
\text { concept of } \\
\text { obligatory prayer }\end{array}$ & $\begin{array}{l}\text { Performing } \\
\text { obligatory } \\
\text { prayer but not } \\
\text { on regular basis }\end{array}$ & $\begin{array}{l}\text { Always } \\
\text { performing } \\
\text { obligatory } \\
\text { prayer }\end{array}$ & $\begin{array}{l}\text { Performing } \\
\text { obligatory prayer } \\
\text { and encouraging } \\
\text { others to pray }\end{array}$ & \\
\hline $\begin{array}{l}\text { Recommended } \\
\text { Prayer }\end{array}$ & $\begin{array}{l}\text { Blocking } \\
\text { others to } \\
\text { pray }\end{array}$ & $\begin{array}{l}\text { Against the } \\
\text { concept of } \\
\text { recommended } \\
\text { prayer }\end{array}$ & $\begin{array}{l}\text { Not performing } \\
\text { recommended } \\
\text { prayer }\end{array}$ & $\begin{array}{l}\text { Performing } \\
\text { recommended } \\
\text { prayer but not } \\
\text { on regular basis }\end{array}$ & $\begin{array}{l}\text { Always } \\
\text { performing } \\
\text { recommended } \\
\text { prayer }\end{array}$ & \\
\hline $\begin{array}{l}\text { Congregational } \\
\text { Prayer }\end{array}$ & $\begin{array}{l}\text { Blocking } \\
\text { others to } \\
\text { pray }\end{array}$ & $\begin{array}{l}\text { Against the } \\
\text { concept of } \\
\text { recommended } \\
\text { prayer }\end{array}$ & $\begin{array}{l}\text { Not performing } \\
\text { prayer in } \\
\text { congregation }\end{array}$ & $\begin{array}{l}\text { Performing } \\
\text { prayer in } \\
\text { congregation } \\
\text { but not on } \\
\text { regular basis }\end{array}$ & $\begin{array}{l}\text { Always } \\
\text { Performing prayer } \\
\text { in congregation }\end{array}$ & \\
\hline $\begin{array}{l}\text { Obligatory } \\
\text { Fasting }\end{array}$ & $\begin{array}{l}\text { Blocking } \\
\text { others to } \\
\text { undertake } \\
\text { fasting }\end{array}$ & $\begin{array}{l}\text { Against the } \\
\text { concept of } \\
\text { fasting }\end{array}$ & $\begin{array}{l}\text { Not fully } \\
\text { performing } \\
\text { obligatory } \\
\text { fasting }\end{array}$ & $\begin{array}{l}\text { Performing } \\
\text { only obligatory } \\
\text { fasting }\end{array}$ & $\begin{array}{l}\text { Performing } \\
\text { obligatory fasting } \\
\text { and encouraging } \\
\text { others to } \\
\text { undertake fasting }\end{array}$ & \\
\hline $\begin{array}{l}\text { Recommended } \\
\text { Fasting }\end{array}$ & $\begin{array}{l}\text { Blocking } \\
\text { others to } \\
\text { undertake } \\
\text { fasting }\end{array}$ & $\begin{array}{l}\text { Against the } \\
\text { concept of } \\
\text { fasting }\end{array}$ & $\begin{array}{l}\text { Not performing } \\
\text { recommended } \\
\text { fasting }\end{array}$ & $\begin{array}{l}\text { Performing } \\
\text { recommended } \\
\text { fasting but not } \\
\text { on regular basis }\end{array}$ & $\begin{array}{l}\text { Always } \\
\text { performing } \\
\text { recommended } \\
\text { fasting }\end{array}$ & $\begin{array}{c}\text { Average } \\
\text { score for } \\
\text { spiritually } \\
\text { poor }\end{array}$ \\
\hline Zakat and Infak & $\begin{array}{l}\text { Blocking } \\
\text { others to pay } \\
\text { zakat and } \\
\text { infak }\end{array}$ & $\begin{array}{l}\text { Against the } \\
\text { concept of zakat } \\
\text { and infak }\end{array}$ & $\begin{array}{l}\text { Not paying } \\
\text { infak at least } \\
\text { once in a year }\end{array}$ & $\begin{array}{l}\text { Paying zakat } \\
\text { al-fitr and } \\
\text { zakat al-maal }\end{array}$ & $\begin{array}{l}\text { Paying zakat al- } \\
\text { fitr, zakat al-maal, } \\
\text { and infak }\end{array}$ & $\begin{array}{c}\text { household } \\
\text { is equal to } \\
3 \\
(\mathrm{SS}=3)\end{array}$ \\
\hline $\begin{array}{l}\text { Reciting Al- } \\
\text { Quran }\end{array}$ & $\begin{array}{l}\text { Blocking } \\
\text { others to } \\
\text { recite Al- } \\
\text { Quran }\end{array}$ & $\begin{array}{l}\text { Never recite Al- } \\
\text { Quran }\end{array}$ & $\begin{array}{l}\text { Recite Al- } \\
\text { Quran but not } \\
\text { on daily basis }\end{array}$ & $\begin{array}{l}\text { Recite Al- } \\
\text { Quran in daily } \\
\text { basis less than } \\
1 \text { juz }\end{array}$ & $\begin{array}{l}\text { Recite Al-Quran } \\
\text { in daily basis at } \\
\text { least } 1 \text { juz }\end{array}$ & \\
\hline $\begin{array}{l}\text { Acquiring } \\
\text { Islamic } \\
\text { Knowledge }\end{array}$ & $\begin{array}{l}\text { Blocking } \\
\text { others to } \\
\text { Islamic } \\
\text { Knowledge }\end{array}$ & $\begin{array}{l}\text { Never acquire } \\
\text { Islamic } \\
\text { knowledge }\end{array}$ & $\begin{array}{l}\text { Seldom acquire } \\
\text { Islamic } \\
\text { knowledge }\end{array}$ & $\begin{array}{l}\text { Often acquire } \\
\text { Islamic } \\
\text { knowledge }\end{array}$ & $\begin{array}{l}\text { Acquire Islamic } \\
\text { knowledge in } \\
\text { regular basis }\end{array}$ & \\
\hline $\begin{array}{l}\text { Religious } \\
\text { gathering } \\
\text { attendance }\end{array}$ & $\begin{array}{l}\text { Blocking } \\
\text { others to } \\
\text { attend } \\
\text { religious } \\
\text { gathering }\end{array}$ & $\begin{array}{l}\text { Never attend } \\
\text { religious } \\
\text { gathering }\end{array}$ & $\begin{array}{l}\text { Seldom attend } \\
\text { religious } \\
\text { gathering }\end{array}$ & $\begin{array}{l}\text { Often attend } \\
\text { religious } \\
\text { gathering }\end{array}$ & $\begin{array}{l}\text { Attend religious in } \\
\text { regular basis }\end{array}$ & \\
\hline $\begin{array}{l}\text { Household } \\
\text { Environment }\end{array}$ & $\begin{array}{l}\text { Forbid } \\
\text { ibaadah }\end{array}$ & $\begin{array}{l}\text { Against } \\
\text { implementation } \\
\text { of ibaadah }\end{array}$ & $\begin{array}{l}\text { Consider } \\
\text { ibaadah as } \\
\text { private matter } \\
\text { for household } \\
\text { member }\end{array}$ & $\begin{array}{l}\text { Support } \\
\text { execution of } \\
\text { ibaadah }\end{array}$ & $\begin{array}{l}\text { Creating } \\
\text { environment } \\
\text { which obligates } \\
\text { execution of } \\
\text { ibaadah }\end{array}$ & \\
\hline $\begin{array}{l}\text { Government } \\
\text { Policy } \\
\text { Environment }\end{array}$ & $\begin{array}{l}\text { Forbid } \\
\text { ibaadah }\end{array}$ & $\begin{array}{l}\text { Against } \\
\text { implementation } \\
\text { of ibaadah }\end{array}$ & $\begin{array}{l}\text { Consider } \\
\text { ibaadah as } \\
\text { private matter }\end{array}$ & $\begin{array}{l}\text { Support } \\
\text { execution of } \\
\text { ibaadah }\end{array}$ & $\begin{array}{l}\text { Creating } \\
\text { environment } \\
\text { which obligates } \\
\text { execution of } \\
\text { ibaadah }\end{array}$ & \\
\hline
\end{tabular}

Source: Beik and Arsyianti (2015) with some extensions

The indicator of reading $A l$ Quran is in line with some Quranic verses that show the significance of the Holy Book and therefore Muslim should learn, read and implements its contents in all aspects of their life. For example, in the Quran 2: 2, Allah SWT says, "This is the Book about which there is no doubt, a guidance for those conscious of Allah." People who conscious of Allah SWT are those who have taqwa, piety, righteousness, fear and love of Allah and those who take great care to avoid His displeasure. The important position of Al-Quran in the Muslim's life as a guidance can also be found in the Quran 29: 45, 38: 1, 50: 1, 56: 77-80 and 85: 21. 
In terms of the endeavor for acquiring Islamic knowledge as well as attending religious gathering, this is based on the important role of knowledge in the religion. Islam encourages people to have knowledge as Allah SWT states, "...Allah will raise those who have believed among you and those who were given knowledge by degrees." (Quran 58: 11). This verse shows the importance of the knowledge acquirement process. People are encouraged to obtain useful knowledge particularly the one that can generate better understanding on Islam. There are also many verses that indicate the role of knowledge for Muslim such as the Quran 3: 18, 20: 114 and 39: 9. Following the CIBEST model, spiritual standard that separates spiritually poor households and spiritually rich households is determined to be equal to 3 (vide Table 1). Mathematically, it can be written as follows.

$$
S S=3
$$

Where:

$S S=$ Standard for spiritual poverty

The general spiritual condition of households in one country can be formulated as follows.

$$
S A=\sum_{k=1}^{N} \frac{S H k}{N}
$$

Where:

$S A=$ Average score of spiritual condition of the observed households $S H k=$ Actual condition of household $k$

$N=$ The number of households in the sample

If the value of spiritual average ranking of the household is more than its standard (SA > SS), then generally speaking, spiritual condition of population in one place is in good condition. In other words, they are spiritually rich. Similarly, if the value of spiritual average of the household is less than or equal to its standard (SA $\leq$ SS), the residents of that place are spiritually poor.

Another important aspect is related on the calculation of $S H k$. It is obtained from the score of all variables observed in the household. Therefore, equation (8) below provides the formula to compute $S H k$.

$$
\begin{aligned}
& \stackrel{S H a v}{T N H} \\
& =\sum_{h=1}^{A S_{1}+A S_{2}+\cdots+A S_{T N H}} \\
& T N H
\end{aligned}
$$

Where:

SHav = Average score of actual spiritual condition of one household $A S h=$ Actual spiritual score of the household member $h$

$T N H=$ Total number of household member

As for $A S i$, the formula is as follows.

$$
\begin{aligned}
& A S i \\
& =\frac{F S+O P S+R P S+C P S+O F S+R F}{1}
\end{aligned}
$$

Where:

$A S i=$ Actual spiritual score of household member $i$

$O P S=$ Obligatory prayer score

$R P S=$ Recommended prayer score

$C P S=$ Congregational prayer score

$O F S=$ Obligatory fasting score

$R F S=$ Recommended fasting score

$Z S=$ Zakat and infaq score

$A S=$ Reading Al-Quran score

$K S=$ Acquiring Islamic knowledge score

$I G S=$ Islamic gathering attendance score

$H S=$ Household environment score

$G S=$ Government policy environment score

Determination of the number of households in each CIBEST quadrant 
is based on combination of results of material standard (MS) value and spiritual standard (SS) value. There are four probabilities of combination between MS and SS results, namely, both rich and high spirituality, high spirituality but poor, rich but low spirituality, and both poor and low spirituality

When the number of household in each quadrant is known, the calculation of all indices becomes easier. Combining all values of falah index, material poverty index, spiritual poverty index and absolute poverty index, we will get total values of those indices to be equal to 1 . This is called as the generalized CIBEST model.

$$
\begin{aligned}
\text { CIBEST Model } & =1 \\
& =F+M p \\
& +S p+A p
\end{aligned}
$$

According to equation (10), total summation of all indices must be equal to one. These indices could be utilized in mapping the population, in which quadrant that most of the population lives. It will assist the government to design policy strategy that can be effectively executed.

In terms of income inequality, the study uses Deciles, Gini coefficient and Atkinson index as the analytical tools. McConnell et al (2015) define Gini coefficient as a numerical measure of the overall distribution of income. The value lies between 0 to 1 , where 0 exhibits perfect equality and 1 represents perfect inequality. Based on Patmawati (2006), the calculation of Gini coefficient is as follows.

$$
\begin{array}{r}
G=1-\sum(a b)(b d \\
+a c)
\end{array}
$$

Where:

$G=$ Gini coefficient

$a b=$ The value based on population division $b d=$ Percentage of income received by population

$a c=$ Percentage of population

The interpretations of Gini coefficient results are as follows. If the post-zakat Gini coefficient may appear smaller than the pre-zakat Gini coefficient, to suggest the impact of zakat distribution on income inequality reduction.

Another income inequality measurement is Atkinson Index. It is basically based on the social welfare evaluation of income distribution. Patmawati (2006) argued that this index has two major objectives. First, to quantify the differences in inequality between the two distributions to indicate the income distribution of the post-zakat distribution is more equal than the income distribution of the pre-zakat distribution. Second, to measure the degree of welfare loss of the society due to inequality in the income distribution of the society. This is important so that we can know whether the welfare loss of the society is reduced with the distribution of zakat.

On the other hand, Golan et al (2001) argue that this measure has several desirable properties. First, the Atkinson index has a dollardenominated (currency-denominated) interpretation. Second, the measure for the entire population can be decomposed into within-groups and between-groups welfare measures for subgroup of the population. Third, changing the single parameter that indexes the Atkinson measure changes the weight the welfare index places on relative increases of wealth at the lower end of the income distribution. Fourth, it can be derived axiomatically to be consistent with a welfare maximization model.

The formula of Atkinson index is given below. 


$$
I=1-\frac{Y_{E D E}}{\mu}
$$

Where:

$I=$ Atkinson index

$Y_{E D E}=$ Equally distributed equivalent level of income.

$\mu=$ Mean income distribution of the population

The interpretation of this Atkinson index is based on its pre and post zakat values. If the value of postzakat Atkinson index may appear smaller than the value of pre-zakat Atkinson index, it can be concluded that zakat distribution is able to reduce the welfare loss of the society, and vice versa.

\section{RESULTS AND ANALYSIS}

\section{Demographic Characteristics}

The following Table 2 presents respondents' profile based on areas. While urban area is represented by three cities including Bogor, Sukabumi and Depok, rural area is only represented by two regencies namely Bogor and Sukabumi. It appears that around two-third of the respondents live in rural area, while only one-third of the respondents are from the urban area. This can be understood as more people live in rural area as compared to the urban area.

The following Table 3 exhibits demographic characteristics of the respondents in urban and rural areas. In terms of gender, it appears that the current finding is contradicted with the conventional wisdom where maleheaded households dominate characteristics of the respondents by approximately two-third and four-fifth in urban and rural areas respectively. In relation with marital status, nearly two-third of the household heads are married in both areas followed by the widowed and single household heads.

Table 2. Respondents' Profile based on Area

\begin{tabular}{llrr}
\hline & Demographic Characteristics & Frequency & Percentage \\
\hline Urban & Bogor City & 300 & 63.03 \\
& Sukabumi City & 76 & 15.97 \\
& Depok City & 100 & 21.00 \\
& Total & 476 & 100.00 \\
\hline Rural & Bogor Regency & 333 & 39.98 \\
& Sukabumi Regency & 500 & 60.02 \\
& Total & 833 & 100.00 \\
\hline Total & Urban & 476 & 36.36 \\
& Rural & 833 & 63.63 \\
& Total & 1,309 & 100.00 \\
\hline
\end{tabular}


Table 3. Respondents' Demographic Characteristics

\begin{tabular}{|c|c|c|c|}
\hline \multirow{2}{*}{\multicolumn{2}{|c|}{ Demographic Characteristics }} & \multicolumn{2}{|c|}{ Percentage } \\
\hline & & Urban & Rural \\
\hline \multirow{2}{*}{ Gender } & Man & 67.4 & 79.7 \\
\hline & Woman & 32.6 & 20.3 \\
\hline \multirow{3}{*}{ Status } & Married & 66.8 & 81.9 \\
\hline & Single & 8.2 & 0.7 \\
\hline & Divorced & 25.0 & 17.4 \\
\hline \multirow{4}{*}{ Age Groups } & Juvenile $(12-25$ yo $)$ & 5.7 & 1.0 \\
\hline & Adults $(26-45$ yo) & 36.8 & 43.6 \\
\hline & Seniors $(46-65$ yo) & 45.0 & 47.9 \\
\hline & Elderly (> 65 yo) & 12.6 & 7.5 \\
\hline \multirow{7}{*}{$\begin{array}{l}\text { Formal } \\
\text { Education }\end{array}$} & No Formal Education & 4.2 & 1.6 \\
\hline & Elementary School & 37.8 & 46.0 \\
\hline & Junior High School & 22.5 & 23.3 \\
\hline & Senior High School & 30.9 & 25.6 \\
\hline & Associate's Degree & 1.5 & 1.2 \\
\hline & Bachelor Degree & 2.5 & 3.1 \\
\hline & Others & 0.6 & 0.2 \\
\hline \multirow{2}{*}{$\begin{array}{l}\text { Informal } \\
\text { Education }\end{array}$} & Yes & 41.0 & 53.4 \\
\hline & No & 59.0 & 46.6 \\
\hline \multirow{8}{*}{ Jobs } & Employee & 11.1 & 8.8 \\
\hline & Housewife & 4.6 & 2.5 \\
\hline & Farmer & 1.3 & 10.8 \\
\hline & Entrepreneur & 21.6 & 26.2 \\
\hline & Labor & 20.2 & 21.5 \\
\hline & Industry Sector & 2.3 & 1.7 \\
\hline & Service Sector & 29.4 & 12.7 \\
\hline & Others & 9.5 & 15.8 \\
\hline
\end{tabular}

Based on the age of the head of households in both areas, it is surprising to observe that almost half of the head of households are seniors category (46 to 65 years old), followed by adults (26-45 years old), elderly (more than 65 years old) and juvenile (12-25 years old) categories. The finding suggests that the respondents are mostly at their economically production age, i.e. between 46 to 65 years old.

It is also found that majority of household heads in both areas pursue formal education up to elementary school level closely followed by senior and junior high school levels. There are approximately 4 percent of the household heads that hold diploma and bachelor degree certificates. Only less than 1 percent of the respondents hold such other level of formal education as Islamic boarding school (Pesantren). However, it is surprising to observe that the household heads who never attend any formal education seems to be higher in the urban area as compared in the rural area. This phenomenon might be linked to the increase in urban poverty due to internal migration from rural to urban areas.

In terms of informal education, it is interesting to note that there exists 
opposite evidence in both areas. While majority of urban household heads have never undergone any informal education, majority rural household heads have attended such informal education as routine Islamic gathering held near their places. This might reflect two facts. First, the awareness of the household heads in urban area to attend informal education might be lower. Second, the presence of such informal education as routine Islamic gathering in urban neighborhood might not be as many as that of rural area.

In relation with the jobs of household heads, worker in service sector dominates the occupation of household heads in urban area by nearly one-third of the total respondents; followed by entrepreneur (21.6 percent), factory labour (20.2 percent), employee (11.1 percent), housewife (4.6 percent), worker in industry sector (2.3) and farmer (1.3 percent). On the other hand, entrepreneur constitutes the highest portion of occupation of the rural household heads by 26.2 percent; followed by factory labour (21.5 percent), worker in service sector (12.7 percent), farmer (10.8 percent), employee (8.8), housewife (2.5 percent) and worker in industry sector (1.7 percent).

The following Table 4 the types of zakat distribution programs received by the households. It appears to be overwhelming predominance of consumption-based program over production-based program in urban area. On the other hand, productionbased program shares two-thirds of the total zakat distribution program in rural area. This finding suggests that BAZNAS in rural area provides more empowerment programs as compared to BAZNAS in urban area. As a consequence, the average value of zakat fund received by rural households is also higher than urban households as production-based programs attempt to empower mustahik through entrepreneurship and business initiation or development. The difference of zakat fund values received by respondents in urban and rural area is statistically significant at 5 percent.

Table 4. Respondents' Profile based on Types of Zakat Distribution Programs

\begin{tabular}{lrrrr}
\hline \multirow{2}{*}{ Types of Zakat Distribution } & \multicolumn{4}{c}{ Area } \\
\cline { 2 - 5 } \multicolumn{1}{c}{ Program } & \multicolumn{2}{c}{ Urban } & \multicolumn{2}{c}{ Rural } \\
\cline { 2 - 5 } & Frequency & Percentage & Frequency & Percentage \\
\hline Consumption-based Program & 367 & 77.1 & 250 & 30.0 \\
Production-based Program & 109 & 22.9 & 583 & 70.0 \\
Total & 476 & 100.00 & 833 & 100.0 \\
\hline
\end{tabular}

\section{Poverty Analysis}

Based on the aforementioned division, this study hence wants to analyze whether or not different types of zakat distribution programs have different impacts to the observed households in terms of poverty alleviation. The following Table 5 provides the result. The figures in the parentheses represent the change in the four indices due to the presence of zakat distribution programs.

According to Table 5, it is observed that there is difference of the performance of the four indices of the households in urban and rural areas prior to the zakat distribution programs. While in urban area consumption-based recipients have 
worse performance in all indices, in rural area they have better performance (vide column 1 to 4 ). This also shows different standards of zakat recipients' selection done by amil in urban and rural areas. It seems that the priority of consumption-based programs in urban area belongs to the groups who are economically and spiritually poor while the production-based programs are for those who perform better material and spiritual conditions. On the other hand, majority of productionbased programs in rural area are for those who are economically and spiritually poor.

Table 5. CIBEST Index based on Zakat Programs

\begin{tabular}{|c|c|c|c|c|c|c|c|c|}
\hline \multirow[t]{3}{*}{ Urban } & \multicolumn{4}{|c|}{ Before } & \multicolumn{4}{|c|}{ After } \\
\hline & FI & MPI & SPI & API & FI & MPI & SPI & API \\
\hline & (1) & $(2)$ & (3) & (4) & $(5)$ & $(6)$ & $(7)$ & $(8)$ \\
\hline Consumption & 0.09 & 0.71 & 0.01 & 0.18 & $\begin{array}{c}0.11 \\
(+22.22)\end{array}$ & $\begin{array}{c}0.75 \\
(+5.63)\end{array}$ & $\begin{array}{c}0.01 \\
(0.00)\end{array}$ & $\begin{array}{c}0.12 \\
(-33.33)\end{array}$ \\
\hline Production & 0.42 & 0.32 & 0.19 & 0.06 & $\begin{array}{c}0.59 \\
(+40.48) \\
\end{array}$ & $\begin{array}{c}0.35 \\
(+9.38) \\
\end{array}$ & $\begin{array}{c}0.04 \\
(-78.95) \\
\end{array}$ & $\begin{array}{c}0.02 \\
(-66.67) \\
\end{array}$ \\
\hline \multirow[t]{2}{*}{ Rural } & \multicolumn{4}{|c|}{ Before } & \multicolumn{4}{|c|}{ After } \\
\hline & $\begin{array}{l}\text { FI } \\
(1)\end{array}$ & $\begin{array}{c}\text { MPI } \\
(2)\end{array}$ & $\begin{array}{l}\text { SPI } \\
(3)\end{array}$ & $\begin{array}{c}\text { API } \\
(4)\end{array}$ & $\begin{array}{l}\text { FI } \\
(5)\end{array}$ & $\begin{array}{l}\text { MPI } \\
(6)\end{array}$ & $\begin{array}{l}\text { SPI } \\
(7)\end{array}$ & $\begin{array}{c}\text { API } \\
(8)\end{array}$ \\
\hline Consumption & 0.10 & 0.84 & 0.00 & 0.06 & $\begin{array}{c}0.12 \\
(+20.00)\end{array}$ & $\begin{array}{c}0.80 \\
(-4.76)\end{array}$ & $\begin{array}{c}0.02 \\
(+100.00)\end{array}$ & $\begin{array}{c}0.06 \\
(0.00)\end{array}$ \\
\hline Production & 0.03 & 0.68 & 0.04 & 0.25 & $\begin{array}{c}0.12 \\
(+300.00)\end{array}$ & $\begin{array}{c}0.81 \\
(+19.12) \\
\end{array}$ & $\begin{array}{c}0.01 \\
(-75.00)\end{array}$ & $\begin{array}{c}0.06 \\
(-76.00)\end{array}$ \\
\hline
\end{tabular}

Note: FI: Falah Index

MPI: Material Poverty Index

SPI: Spiritual Poverty Index

API: Absolute Poverty Index

One year after zakat distribution programs, it is observed that production-based programs give higher increase of the falah index both in urban and rural areas. This is evident from the figures in the parentheses in column (5) showing that the falah index of households who received production-based programs increases by 40.48 and 300.00 percentage points in urban and rural areas respectively, while households who obtained consumption-based programs rise by only around 20.00 percentage points in both areas. Given the spiritual and business supervision from amil officers during the programs, these results confirm that the production-based programs are intended to empower the zakat recipients in which in the long run the welfare in terms of material and spiritual of the recipients can be realized.

In a similar vein, the absolute poverty index of the households participating in the production-based programs can be reduced greater as compared to the households participating the consumption-based programs in urban and rural areas as evident in the figures in the parentheses of column (8). This also reflects that production-based programs have more salutary effect in reducing material and spiritual poverty because of the presence of business and spiritual supervision of amil officers.

When examining the material poverty index, it is interesting to note 
that except for the households participating consumption-based programs in rural area the values increase as a result of migration of the households from absolute poverty quadrant (vide column 6). In this case, there are households who are better off in terms of their spiritual condition only but still fall under material poverty in the presence of zakat distribution programs.

On the other hand, the spiritual poverty index of the households participating production-based programs in urban and rural areas can be reduced substantially by approximately 80.00 percentage points as presented in column (7). This shows the important roles of productionbased programs concomitant with the spiritual supervision of amil officers for the zakat recipients. In the absence of spiritual supervision, the spiritual poverty index of the households joining consumption-based programs in both areas remain and even increase.

Given these results, the percentage of production-based zakat distribution programs should be increased for the future zakat distribution programs without neglecting the priority standard according to the shariah. Through production-based distribution programs, zakat can noticeably empower the poor society by targeting the zakat recipients who are in the production age and have no physical constraint. Therefore the role of zakat in alleviating material and spiritual poverty can be realized.

\section{Income Inequality Analysis}

The following Table 6 presents the income distribution of households who are given consumption-based programs in urban and rural areas. It is observed that prior to consumption-based zakat distribution programs in urban and rural areas, the bottom 20 percent only enjoy less than one twentieth while the top 20 percent share almost a half indicating the existence of huge income gap among the groups. This is evident from the figures in column (1).

One year after zakat programs are disbursed, it is interesting to note that the presence of zakat distribution programs improve the income share of the bottom seven deciles indicated by the increase of their income share as evident from the figures in column (5). Meanwhile, the top 30 percent decreases its income share by approximately 173 percentage points as presented in column (5).

Table 6. Size of Distribution of Household Monthly Income of Households Before and One Year After Participating Consumption-based Zakat Distribution Programs based on Deciles in Urban and Rural Areas

\begin{tabular}{|c|c|c|c|c|c|c|}
\hline \multirow[t]{3}{*}{ No } & \multirow{3}{*}{$\begin{array}{c}\text { Percentage } \\
\text { of } \\
\text { Population }\end{array}$} & \multicolumn{4}{|c|}{ Percentage Share in Total Income } & \multirow{3}{*}{$\begin{array}{l}\text { Percentage } \\
\text { Point of } \\
\text { the Gap } \\
\text { (b-a) } \\
(5)\end{array}$} \\
\hline & & \multicolumn{2}{|c|}{ Before } & \multicolumn{2}{|c|}{ After } & \\
\hline & & $\begin{array}{l}\text { Deciles } \\
\text { (a) } \\
\text { (1) }\end{array}$ & $\begin{array}{c}\text { Cumulative } \\
\text { Deciles } \\
\text { (2) }\end{array}$ & $\begin{array}{c}\text { Deciles } \\
\text { (b) } \\
\text { (3) }\end{array}$ & $\begin{array}{c}\text { Cumulative } \\
\text { Deciles } \\
\text { (4) }\end{array}$ & \\
\hline 1 & $\mathrm{D}_{1}$ & 1.34 & 1.34 & 1.63 & 1.63 & $(+29)$ \\
\hline 2 & $\mathrm{D}_{2}$ & 2.69 & 4.03 & 2.90 & 4.53 & $(+21)$ \\
\hline 3 & $D_{3}$ & 3.87 & 7.90 & 4.38 & 8.92 & $(+51)$ \\
\hline 4 & $\mathrm{D}_{4}$ & 5.44 & 13.34 & 5.78 & 14.69 & $(+34)$ \\
\hline 5 & $\mathrm{D}_{5}$ & 7.07 & 20.40 & 7.14 & 21.83 & $(+7)$ \\
\hline 6 & $\mathrm{D}_{6}$ & 8.47 & 28.88 & 8.54 & 30.38 & $(+7)$ \\
\hline 7 & $\mathrm{D}_{7}$ & 10.53 & 39.41 & 10.73 & 41.11 & $(+20)$ \\
\hline
\end{tabular}




\begin{tabular}{ccccccc}
\hline 8 & $\mathrm{D}_{8}$ & 13.53 & 52.94 & 13.35 & 54.46 & $(-18)$ \\
9 & $\mathrm{D}_{9}$ & 17.67 & 70.60 & 16.89 & 71.35 & $(-78)$ \\
10 & $\mathrm{D}_{10}$ & 29.40 & 100.00 & 28.65 & 100.00 & $(-75)$ \\
\hline \multicolumn{3}{c}{ The above findings are also } & \multicolumn{2}{l}{ evident from the figures in column (3), } \\
evidenced from the following Gini & \multicolumn{2}{l}{ although the change only depicts a } \\
coefficient and Atkinson index as & \multicolumn{2}{l}{$\begin{array}{l}\text { marginal reduction (0.039 and 0.067). } \\
\text { presented in the following Table 7. }\end{array}$} \\
According to the table, it appears that & $\begin{array}{l}\text { This indicates that income inequality } \\
\text { can be marginally improved and the }\end{array}$ \\
Gini coefficient and Atkinson index & welfare loss can also be reduced \\
can be reduced only in urban area one & among zakat beneficiaries in urban \\
year after consumption-based zakat & area.
\end{tabular}
distribution programs are conducted as

Table 7. Gini Coefficient and Atkinson Index Before and One Year after Joining Consumption based Zakat Distribution Programs

\begin{tabular}{clccc}
\hline Areas & $\begin{array}{c}\text { Income } \\
\text { Inequality } \\
\text { Measures }\end{array}$ & $\begin{array}{c}\text { Before Zakat } \\
\text { Distribution } \\
\text { Program } \\
(1)\end{array}$ & $\begin{array}{c}\text { One Year After } \\
\text { Zakat } \\
\text { Distribution } \\
\text { Program } \\
(2)\end{array}$ & $\begin{array}{c}\text { Change Index } \\
(3)\end{array}$ \\
\hline Urban & GC & 0.415 & 0.376 & $(-0.039)$ \\
& AI & 0.559 & 0.492 & $(-0.067)$ \\
\hline Rural & GC & 0.441 & 0.449 & $(+0.008)$ \\
& AI & 0.631 & 0.639 & $(+0.008)$ \\
\hline Total & GC & 0.426 & 0.406 & $(-0.020)$ \\
& AI & 0.590 & 0.560 & $(-0.030)$ \\
\hline
\end{tabular}

GC: Gini Coefficient

AI: Atkinson Index

In terms of production-based zakat distribution programs in urban and rural areas, it is observed in the following Table 8 that the income distribution among production-based zakat distribution programs one year after the program is conducted appears to be better off as presented in column (5). According to the table, it is surprising to observe that the income share enjoyed by the bottom 7 deciles goes up by 170 percentage points while the top 3 deciles reduces their income share by 170 percentage points. These changes are similar with the aforementioned consumption-based zakat distribution programs. Therefore our finding suggests the similar impact between consumption and production- based programs on the income inequality reduction.

This finding is also supported by the values of Gini coefficient and Atkinson index as presented in the following Table 9. It appears that the marginal reduction in income inequality and welfare loss only apply in the beneficiaries in the rural area as evident from the figures in column (3). In other words, both types of programs have more salutary effect on the zakat recipients in rural area than that of in urban area. From our observation, this might happen due to the presence of supervision program from the amil officers in rural area. 
Table 8. Size of Distribution of Household Monthly Income of Households Before and One Year After Participating Production-based Zakat Distribution Programs based on Deciles in Urban and Rural Areas

\begin{tabular}{|c|c|c|c|c|c|c|}
\hline \multirow[t]{3}{*}{ No } & \multirow{3}{*}{$\begin{array}{l}\text { Percentage } \\
\text { of } \\
\text { Population }\end{array}$} & \multicolumn{4}{|c|}{ Percentage Share in Total Income } & \multirow{3}{*}{$\begin{array}{l}\text { Percentage } \\
\text { Point of } \\
\text { the Gap } \\
\text { (b-a) } \\
\text { (5) }\end{array}$} \\
\hline & & \multicolumn{2}{|c|}{ Before } & \multicolumn{2}{|c|}{ After } & \\
\hline & & $\begin{array}{l}\text { Deciles } \\
\text { (a) } \\
\text { (1) }\end{array}$ & $\begin{array}{l}\text { Cumulative } \\
\text { Deciles } \\
\text { (2) }\end{array}$ & $\begin{array}{l}\text { Deciles } \\
\text { (b) } \\
\text { (3) }\end{array}$ & $\begin{array}{c}\text { Cumulative } \\
\text { Deciles } \\
\text { (4) }\end{array}$ & \\
\hline 1 & $D_{1}$ & 1.61 & 1.61 & 1.82 & 1.82 & $(+29.64)$ \\
\hline 2 & $\mathrm{D}_{2}$ & 3.27 & 4.88 & 3.40 & 5.22 & $(+21.09)$ \\
\hline 3 & $D_{3}$ & 4.34 & 9.22 & 4.61 & 9.82 & $(+51.00)$ \\
\hline 4 & $\mathrm{D}_{4}$ & 5.69 & 14.92 & 5.62 & 15.45 & $(+33.97)$ \\
\hline 5 & $\mathrm{D}_{5}$ & 6.48 & 21.40 & 6.96 & 22.41 & $(+7.58)$ \\
\hline 6 & $\mathrm{D}_{6}$ & 7.84 & 29.24 & 8.12 & 30.53 & $(+6.74)$ \\
\hline 7 & $\mathrm{D}_{7}$ & 9.20 & 38.44 & 9.43 & 39.96 & $(+20.10)$ \\
\hline 8 & $\mathrm{D}_{8}$ & 11.44 & 49.87 & 11.53 & 51.50 & $(-17.97)$ \\
\hline 9 & $\mathrm{D}_{9}$ & 15.80 & 65.67 & 15.79 & 67.29 & $(-77.52)$ \\
\hline 10 & $\mathrm{D}_{10}$ & 34.33 & 100.00 & 32.71 & 100.00 & $(-74.62)$ \\
\hline
\end{tabular}

Table 9. Gini Coefficient and Atkinson Index Before and One Year after Joining Production based Zakat Distribution Programs

\begin{tabular}{clccc}
\hline Areas & $\begin{array}{c}\text { Income } \\
\text { Inequality } \\
\text { Measures }\end{array}$ & $\begin{array}{c}\text { Before Zakat } \\
\text { Distribution } \\
\text { Program } \\
(1)\end{array}$ & $\begin{array}{c}\text { One Year After } \\
\text { Zakat } \\
\text { Distribution } \\
\text { Program } \\
(2)\end{array}$ & $\begin{array}{c}\text { Change Index } \\
(3)\end{array}$ \\
\hline Urban & GC & 0.352 & 0.366 & $(+0.014)$ \\
& AI & 0.569 & 0.586 & $(+0.017)$ \\
\hline Rural & GC & 0.396 & 0.3788 & $(-0.0172)$ \\
& AI & 0.459 & 0.417 & $(-0.042)$ \\
\hline Total & GC & 0.428 & 0.410 & $(-0.018)$ \\
& AI & 0.505 & 0.467 & $(-0.038)$ \\
\hline
\end{tabular}

GC: Gini Coefficient

AI: Atkinson Index

\section{CONCLUSION AND RECOMMENDATION}

This study suggests that the present zakat distribution programs conducted by BAZNAS can significantly alleviate poverty and reduce income inequality among zakat beneficiaries. It is observed that one year after receiving zakat programs, production-based programs have higher increase of the material and spiritual condition (represented by falah index) by 300 percentage points while households who obtained consumption-based programs rise by only 20 percentage points.

It is also found that the Gini coefficient decreases by 0.020 points while Atkinson index falls by 0.030 points indicating that the income inequality and social welfare loss among observed zakat beneficiaries of consumption-based programs are improved due to the presence of zakat programs. Besides, the similar impact 
also applies in the beneficiaries of production-based zakat distribution programs where the income inequality and social welfare loss can be reduced by 0.018 and 0.038 points one year after the programs are conducted. To conclude, this study has substantiated the role of consumption and production-based zakat programs for poverty alleviation and income inequality reduction among zakat beneficiaries under consideration.

There are three recommendations can be drawn from the current findings. First, this study suggests for BAZNAS to improve the portion of production-based zakat distribution programs as they are found to have better effects specifically in reducing poverty of the beneficiaries. Second, continuous business and spiritual supervision programs from amil officers should be also improved in order to empower the beneficiaries and hence to achieve their independences status in the long run. Third, BAZNAS should give more attention on the selection process of the prospective beneficiaries so that the zakat recipients belong those who are eligible being mustahiq as this study finds there are households who are in the first quadrant prior to zakat distribution programs indicating that they are already above poverty line standard.

\section{REFERENCES}

Al-Ghazali. (1980). Ihya Ulum al Din. Beirut: Darul Fikr.

Anriani. (2010). Analisis Dampak Zakat terhadap tingkat Kemiskinan Mustahik Studi Kasus: Pendayagunaan Zakat oleh BAZ Kota Bogor di Tiga Kecamatan Kota Bogor (Undergraduate). Bogor Agricultural University.
Badan Amil Zakat Nasional (BAZNAS) Report (2015). Jakarta: BAZNAS.

Beik, I. S. \& Ayuniyyah, Q. Fiqh Asnaf in the Distribution of Zakat: Case Study of the National Board of Zakat of Indonesia (BAZNAS). AlIqtishad: Journal of Islamic Economics, 6(2), 201-216.

Beik, I. S., \& Arsyianti, L. D. (2015). Construction of CIBEST Model as Measurement of Poverty and Welfare Indices from Islamic Perspective. Al-Iqtishad: Journal of Islamic Economics, 7(1), 87-104. http://doi.org/10.15408/ijies.v7i $\underline{1.1361}$

Beik, I. S. \& Pratama, C. (2015). Analisis Pengaruh Zakat pada Kesejahteraan Mustahik Model CIBEST. Republika daily: May 28.

Beik, I. S. \& Tsani, T. (2015). Role of Zakat Distribution in Reducing Poverty and Income Inequality in Indonesia. In M. Yusop \& N. Abdullah, Zakat and Poverty Alleviation (pp. 198-217). Kuala Lumpur: IIUM Press.

Beik, I. S. (2013). Economic Role of Zakat in Reducing Poverty and Income Inequality : A Case Study in the Province of DKI Jakarta, Indonesia. Deutschland: LAP Lambert Academic Publishing.

Narayan, D. (2000). Voices of the Poor: Can Anyone Hear Us? (Vol. 1). World Bank Publications.

Patmawati. (2006). Economic Role of Zakat in Reducing Income Inequality and Poverty in Selangor (Ph.D). Universiti Putra Malaya.

Pramanik, A. H. (1993). Development and Distribution in Islam. 
Petaling Jaya: Pelanduk Publications.

Pramanik, A. H. (1998). Poverty from Multidimensional Perspectives: A Micro Level Study of Seven Malaysian Kampungs (Villages). Kuala Lumpur: Cahaya Pantai.

Purnamasari, N. (2010). Analisis Pengaruh Pendayagunaan Zakat, Infaq, dan Shadaqah terhadap Pengurang Kemiskinan Studi Kasus: Pusat Zakat Umat LAZ Persis Garut (Undergraduate). Bogor Agricultural University.

Shirazi, N. S. (1994). An Analysis of Pakistan's Poverty Problem and Its Alleviation through Infaq, (Ph.D). International Islamic University, Islamabad.

Syahhatih, S. I. (1989). Penerapan Zakat dalam Dunia Modern. Translator Anshori Umar Sitanggal. Jakarta: Pustaka Dian dan Antar Kota.
Qurroh Ayuniyyah

International Islamic University

Malaysia

ayuniyyah@gmail.com

Ataul Huq Pramanik

International Islamic University

Malaysia

ataul@iium.edu.my

Norma Md Saad

International Islamic University

Malaysia

norma@iium.edu.my

Muhammad Irwan Ariffin

International Islamic University

Malaysia

irwan@iium.edu.my 